\title{
Notes
}

\section{The Right of Nonrepatriation of Prisoners of War Captured by the United States}

The development of international legal standards for the proper treatment of prisoners of war has historically involved controversy over repatriation at the end of hostilities. The main conflict has been between the obligation to return all captives to the authorities of their native states and the right to retain those who desired not to be repatriated.

Although a recognized duty of captor states to return prisoners developed first, by the end of World War I a countervailing state right not to repatriate those who did not want to be returned was incorporated into many peace treaties and repatriation conventions. ${ }^{1}$ The Geneva Convention of $1929^{2}$ did not speak explicitly to the problem, however, nor was practice following World War II uniform. Some nation states allowed prisoners the choice to remain in the captor state, either due to a shortage of manpower or to fulfill promises given to encourage surrender. ${ }^{3}$ More often, such election was not granted the captured combatants with the result that many were retained against their will. Others were repatriated without an opportunity to exercise such election, with the consequence that

1. The Russian repatriation conventions paid significant attention to this principle. See, e.g., Agreement Between His Majesty's Government and the Soviet Government of Russia for the Exchange of Prisoners, Feb. 12, 1920, art. 4, CMD. No. 587, at 2 (1920), 1 L.N.T.S. 264, 265; Agreement Between Germany and the Soviet Union with Regard to the Mutual Repatriation of Prisoners of War and Interned Civilians, Apr. 19, 1920, art. 1, 2 L.N.T.S. 66, 67. For a summary of other similar reservations in Russian conventions exectited at the close of World War I, see Oral Report of Secretary of State Dean Acheson before the Political and Sec. Comm. of the U.N. General Assembly, Oct. 24, 1952, in D. Acheson, The Problem of Korea 35-39 (Dep't of State Int'l Organization and Conference Series III, No. 88, 1952). The Allies also incorporated the right not to repatriate prisoners into peace treaties and repatriation conventions. See, e.g., Treaty of Versailles, done June 28, 1919, art. 220, 11 Martens Nouveau Recueil (ser. 3) 323, 474; Peace Treaty of St. Germain en Laye, Sept. 10, 1919, art. 166, [1919] Gr. Brit. T.S. No. 11, at 37; Peace Treaty of Trianon, June 4, 1920, art. 150, [1920] Gr. Brit. T.S. No. 10, at 36; Agreement Between Germany and Latvia Concerning the Exchange of their Respective Prisoners, Apr. 20, 1920, art. 1, 2 L.N.T.S. $70,75$.

2. Convention of July 27, 1929, Relative to the Treatment of Prisoners of War, done July 27, 1929, art. 75, 47 Stat. 2021, 2055 (1932), T.S. No. 846, 118 L.N.T.S. 343, 387 [hereinafter cited as Geneva Convention of 1929].

3. Charmatz \& Wit, Repatriation of Prisoners of War and the 1949 Geneva Convention, 62 YALE L.J. 391, 401 (1953). 
many prisoners, fearful of returning home, committed suicide. ${ }^{4}$ It was the retention of captives against their will, however, which was the most recurrent problem; and in order to prohibit it more forcefully, the repatriation provision in the Geneva Convention on prisoners of war of 1949 was altered to read: "Prisoners of war shall be released and repatriated without delay after the cessation of active hostilities."

Notwithstanding the Convention, the issue of repatriation remained unresolved, as became evident during the negotiations to end the Korean War. Demands by thousands of prisoners of war held by the United Nations Command that they not be repatriated led to a dispute between communist and United Nations negotiators which prolonged the negotiations for a year. After the armistice agreement, which included a settlement of the immediate issue, there was no significant repatriation controversy involving the United States until the recent exchange of prisoners in the Vietnam War. Though the issue was not as fully contested as in Korea, there was evidence that some communist captives in South Vietnam expressed the desire not to be repatriated to the North. The Saigon government, for example, released from 10,000 to 20,000 prisoners instead of repatriating them in compliance with the terms of the cease-fire accord; ${ }^{\circ}$ and the International Committee of the Red Cross, which interviewed prisoners of war still held after the earlier release, found many who did not desire to be repatriated. 7 The uncertainty surrounding the return of communist prisoners at the formal end of hostilities in Vietnam suggests once again the unsettled status of the practice of repatriation. It also underscores the need for the United States to reevaluate its international obligations in regard to this issue.

The Korean controversy two decades ago centered on the right of a state to grant the request of a prisoner of war not to be repatriated. At that time neither the United States, which was a forceful advocate of that right, nor the global community at large recog-

4. Comment on dit. 68, Part IV, in International Committee of the Red Cross, Commission OF GovernMent EXPERTS FOR THE STUdY OF CONVENTIONS For THE ProIECTION OF WaR Victims: Preliminary Documents SubMitted by the International Commirtee of the Red Cross 92 (1947) [hereinafter cited as PrelimiNary Documents].

5. Geneva Convention Relative to the Treatment of Prisoners of War of August 12, 1919, done Aug. 12, 1949, art. 118, para. I, [1955] 6 U.S.T. 3316, T.I.A.S. No. 3364, 75 U.N.T.S. 135 [hereinafter cited as the Geneva Convention]. The Geneva Convention of 1929 had proven unsatisfactory because prisoners could be detained until a peace treaty was signed, a formality sometimes omitted and usually delayed after the end of hostilitics.

6. N.Y. Times, Feb. 6, 1973, at 1, col. 8 (city ed.).

7. N.Y. Times, Feb. 13, 1973, at 14, col. 1 (city ed.). 
nized the right of the prisoner himself to refuse repatriation. Such an extension, however, is a necessary final step to complete the protection of the individual captive.

A personal right in international law is usually a benefit which inures to an individual. The term, however, sometimes has a secondary meaning, vital in this context, as a choice which can be personally invoked. Many individual protections can only be asserted by a person's native state, which retains discretion over whether and to what extent to assert the right in each particular case. The personal right of a prisoner of war to refuse repatriation will not be meaningful, however, unless the right may be invoked by the prisoner himself.

The convergence of international law and the policies of the United States suggests that the American government is obligated to respect a right of nonrepatriation when it is asserted by a prisoner of war who can reasonably claim that he would be persecuted for his beliefs, race, or status if he were returned to his native state or to the group to which he was attached at the time of his capture.

This right arises from three interrelated sources. The Geneva Convention of 1949 guaranteed each prisoner of war the personal right to be repatriated, a right which should be interpreted as an option that the prisoner may refuse to exercise. The Convention on the Status of Refugees of $1951^{\mathrm{s}}$ and its subsequent Protocol of $1967^{\circ}$ prohibit all contracting states from returning any refugee to territory where his life or liberty would be threatened on account of his beliefs, race, or status. The prisoner of war refusing repatriation for these reasons brings himself within the terms of the Refugee Convention since he may sever his ties with his native state, even while held in captivity. Finally, principles of customary international law which have developed after the Second World War support the prisoner of war's claim: that an alien should not be returned to territory where he would be persecuted, and that an individual has standing in the international arena to assert personal rights.

\section{The Geneva Convention of 1949}

The Geneva Convention of 1949 Relative to the Treatment of Prisoners of War $^{10}$ (the Geneva Convention), effective on October

8. Done July 28, 1951, 189 U.N.T.S. 150.

9. Done Jan. 31, 1967, [1968] 19 U.S.T. 6224, T.I.A.S. No. 6557.

10. Geneva Convention, supra note 5. The Convention had been ratified or acceded to by 123 nations by the spring of 1970 . Derartanen of State, Treaties in Force 368 (1973). 
21, 1950, and ratified by the United States in 1955, deals in Part Four with the termination of captivity: "Prisoners of war shall be released and repatriated without delay after the cessation of active hostilities."11

During the negotiations after the Korean War the communist nations advocated a literal interpretation of this paragraph, contending that the words of the Convention were self-explanatory. ${ }^{12}$ Such a view has been rejected with respect both to treaty interpretation in general and to the interpretation of this specific treaty. ${ }^{13}$ The interpretation of a treaty must weigh many factors other than the normal meanings of the words taken out of context. Among the most important of these factors is the general purpose of the convention: The proper interpretation is one "which is logical, reasonable and most likely to accord with and to effectuate the larger general purpose which the parties desired the treaty to serve." 14 Other factors which must also be considered are the history of the document, the subsequent conduct of the parties in applying its provisions, changes in relevant circumstances, the signatories' major expectations, and the development of pertinent international law norms. ${ }^{15}$

11. Geneva Convention, art. 118, para. 1.

12. See Speeches of A.Y. Vyshinsky before the United Nations Committee for the Unification and Rchabilitation of Korea, Oct. 29, 1952, Nov, 10, 1952, in Reports of the U.N. Comm. for the Unification and Rehabilitation of Korea, 7 U.N. GAOR, lst Comm. 37, 89 (1952) [hereinafter cited as Vyshinsky Speech].

13. Harvard Research in International Law commented, in regard to its Draft Convention on the Law of Treaties, that the process of interpretation, rightly conceived, cannot be regarded as a merc mechanical one of drawing incvitable meanings from the words in a text or of searching for and discovering some preexisting spccific intention of the parties with regard to every situation arising under a treaty.

It is precisely because the words used in an instrument rarely have exact and single meanings, and because all situations which may arise under it cannot be, or at least are not, forescen and expressly provided for by the parties at the time of its drafting, that the necessity for interpretation occurs.

Harvard Research in International Law, Draft Convention on the Law of Treaties (Comment on Art. 19), 29 AM. J. INT'L L. SuPP. 653, 946 (1935) [hereinafter cited as Harvard Research]. See also Charmatz \& Wit, supra note 3 , at 396 . The Vienna Convention on the Law of Treaties, opened for signature May 22, 1969, 63 A.M. J. INT'L L. 875,8 I $\backslash T^{\prime}$ L Legal Materials 679 (1969), attempted to codify, among other things, the rules on interpretation. Only 32 nations have signed the document, however, and its failure to attract a substantial number of important signatories has rendered it a dead Ietter for the time being. See T. Yoo, ThE Korein War AND THE UNITED Natrons 172 (1965) [hereinafter cited as Yoo], for the view that the repatriation clause of the Convention is especially open to nonliteral interpretation.

1.4. Harvard Research 946. See Case Concerning the Application of the Convention of 1902 Governing the Guardianship of Infants (The Boll Case) (Netherlands v. Sweden), [1958] I.C.J. 55.

15. Harvard Research 948-70. See Advisory Opinion on the Legal Consequences for States of the Continued Presence of South Africa in Namibia (South West Africa) Notwithstanding Security Council Resolution 276 (1970), [1971] I.C.J. 3, 31-32 [hereinafter cited as Namibia Case]; Charmatz \& Wit, supra note 3, at 397; McDougal \& Gardner, The V'eto and the Charter: An Interpretation for Survival, 60 YALE L.J. 258, 262-69, 278.83 (1951). 


\section{A. History and General Purpose}

The history of the Geneva Convention and its general purpose are inseparably intertwined. The Geneva Convention of 1929 had proved ineffective in preventing the suffering of prisoners of war during World War II. ${ }^{16}$ To prevent the repetition of past mistreatment the drafters of the Geneva Convention of 1949 established the humanitarian protection of the individual prisoner and his personal rights as the general purpose of the Convention. Authoritative commentary on the Convention by the International Committee of the Red Cross specifically pointed out that the Convention was concerned with "protecting the individual against abusive use of force," not with guaranteeing the rights of states. ${ }^{17}$ The provisions of the Convention specifically refer to individual rights ${ }^{18}$ and suggest that any interpretation of the Convention should, in compliance with the general purpose of the agreement, improve the condition of the prisoners and in no way lessen the rights accrued. The latter point is bolstered by Articles Six and Seven, which specifically prohibit any diminution of the prisoners' individual rights, and by Articles Six and Nine, which envisage improvement in their condition through channels outside the Convention. ${ }^{19}$

16. See p. 359 supra.

17. International Commitiee of the Red Cross, five Lissons on the Geneva Convivion 5 (J. Pictet ed. 1962) [hereinafter cited as Five Lessons]. The Committec summarized the individual's status under the Convention as follows:

$[T]$ his part of the law of nations . . . is to a certain extent privileged . . . It authorizes and even recommends relationships between individuals, outside of any political allegiance. As Max Huber more aptly put it, "from the strictly legal point of view, a real human right has been created, by virtue of which the individual, his integrity and dignity are defended in the name of a moral principle which rises far above the limits of national law and of political considerations." Id. at 18 .

18. Among the articles specifically referring to individual rights are Article Six ("No special agreement shall adversely . . . restrict the rights which [the Convention] confers upon" the prisoners of war); Irticle Seven ("Prisoners of war may in no circumstances renounce in part or in entirety the rights secured to them by the present Convention"); and Article 14 ("Prisoners of war ... are entitled in all circumstances to respect of their persons and their honour... [and] shall retain the full civil capacity which they enjoyed at the time of their capture . ..."). Other implicit personal guarantees include the rights to refuse to answer questions without being threatcned (Article 17), to send and receive at least two letters and four cards monthly (Article 7l), to practice one's religion, to undertake intellectual and educational pursuits, to have opportunities for physical exercise (Articles 34-38), and to make complaints without fear of reprisal (Article 78). Article 109 further provides that "no sick or injured prisoner of war who is eligible for repatriation ... may be repatriated against his will during hostilities" (Axticle 109).

19. See note 18 supra. Article 6 also provides that any other special agreements made in compliance with the Convention shall continuc as long as the Convention is applicable or until "more favorable measures have been taken with regard [to the prisoners] by one or other of the Parties to the Conflict." Article 9 states, "The provisions of the present Convention constitute no obstacle to the humanitarian activities which the International Committee of the Red Cross or any other impartial humanitarian organization may ... undertake for the protection of prisoners of war or for their relief." 
Forced repatriation of prisoners would run counter to the guarantees provided by the Convention for two distinct reasons. First, it would transform what were intended to be individual rights into states' rights. If the captor state retained the power forcibly to return prisoners of war to their native authorities or if the native state could demand such a return, repatriation as a personal right of the prisoner would be supplanted. A personal right inures to the benefit of the individual as an option, not as an unconditional obligation. To argue that the right to repatriation conferred on prisoners of war was really a right of native states to have prisoners returned would be to change the entire subject of the Convention. Such a view would imply that the prisoner of war is no more than an agent of his state, one to whom guaranteed benefits were given in order to protect the state itself. ${ }^{20}$ That interpretation would ignore the many rights granted to the prisoners, such as freedom of religion and the right to receive mail, which are guarantees meant for the benefit of the individual. Thus, it would set up a dichotomy of purpose and subject in the Convention which it in no way supports. ${ }^{21}$

Second, forced repatriation of a threatened prisoner would not serve to improve his condition in a humanitarian way, as was intended with respect to all articles of the Convention. If a prisoner of war has credible reasons for believing he would be persecuted upon being returned to his native state, it cannot realistically be asserted that an interpretation of Article 118 conceding an absolute right in the captor state to repatriate the prisoner against his will is consistent with the purpose of the Convention. In sum, forced repatriation by the United States would be a violation of the Geneva Convention's purpose and of rights which as a signatory it owes to the individual prisoner.

\section{B. Subsequent Conduct of Parties to the Convention}

The conduct of the nations now party to the Geneva Convention supports an interpretation according the prisoner of war a right to

20. Thesc opposing vicjs of Article 118 played a rolc in the Korean War nego. tiations. Communist spokesmen claimed that Article Seven prevented the prisoner of war from renouncing any rights granted to him and hence that the captor state could enforce the exercise of the right of repatriation. Yoo, supra note 13, at 172. Emphasis on the continued role of the captured combatant as a representative of his country was stressed by the Soviet Union in the United Nations through the speeches of A.Y. Vyshinsky. Vyshinsky Speech, supra note 12. The United Nations Command took the opposing view that "the Convention was a decree of human rights for the prisoners ... and forced repatriation would be in complete contradiction to the humanitarian principle ... of protection for the individual." United Nations Command Report to the Seventh General Assembly, in Five Lessons, supra note 17, at 71 .

21. Yoo 172. 
refuse repatriation for fear of danger to his life or liberty. Shortly after the Convention's adoption, the United Nations General Assembly sought to encourage the release of many prisoners still held by captor states after World War II. The General Assembly's resolution on that occasion is significant in that it specifically categorized the right of repatriation recently agreed to as an opportunity, not an obligation, thereby suggesting that a prisoner could elect not to be returned. ${ }^{22}$

The controversy surrounding interpretation of the Geneva Convention during the negotiations following the Korean War has provided the most important discussion to date of the correct interpretation of the Convention's articles on repatriation. Many prisoners of war held by the United Nations Command had expressed the belief that they would be persecuted if repatriated and had stated that they would violently resist such return. ${ }^{23}$ The Command, with the unanimous agreement of the governments which had forces in Korea, decided it would not forcibly repatriate these captives. The United Nations Command maintained this policy throughout the negotiations, claiming that "all prisoners must be released but only those should be repatriated or turned over to the other side who can be delivered without the application of force." 24 When this position was rejected by the communist negotiators, the debate concerning the proper interpretation of the Geneva Convention was taken to the General Assembly and fully debated. The result was an In-

\section{The Gencral Asscmbly called}

upon all governments still having control of [war victims] to act in conformity with the recognized standards of international conduct and with the [Geneva Convention] which require that, upon the cessation of active hostilities, all prisoners should, with the least possible delay, be given the umrestricted opportunity of repatriation.

Measures for the Peaceful Solution of the Problem of Prisoners of War, G.1. Res. 427, 5 U.N. GAOR Supp. 20, at 45, U.N. Doc. A/1775 (1950) (cmphasis added).

It is also significant that the General Assembly acknowledged the role of "recognized standards of international conduct" with regard to repatriation. See pp. 377-82 infra.

23. Enclosure in letter from Secretary of State J.F. Dulles to the Senate Comm. on Foreign Relations, March 29, 1955, in Hearings on the Geneva Conventions for the Protection of War l'ictims Before the Senate Comm. on Foreign Relations, 84th Cong., 1st Sess. 65-66 (1955) [hereinafter cited as Hearings on the Geneva Conventions]. 24. Forty-Fifth Repori of the United Nations Command Operation in Korea, 27 DeP't State Bull. 272-73 (1952).

The wording of Article 118 that the prisoners were to be "released and repatriated" was thus seized upon by the governments to substantiate their belief that release was required but repatriation was not. Under Secretary of State Robert Murphy stated, Article $118 \ldots$ indicates that the prisoner is to be released immediately after the cessation of hostilities.

We, however, are of the opinion that the prisoner has the right of asylum and that the detaining power has the discretion which will not oblige it to forcibly repatriate the prisoner of war.

Hearings on the Geneva Conventions, supra note 23, at 22. 
dian draft resolution which was adopted by a vote of 54 to 5 with one abstention..$^{25}$ This resolution was noteworthy in three respects. First, it denied the policy of forced repatriation while adhering to the requirements of the Geneva Convention. Second, it referred to the "general spirit of the Convention" as a factor to be considered in applying its terms. Finally, it recognized the concurrent role of "well-established principles and practice of international law" in deciding any questions concerning repatriation.

The eventual agreement on Korean War prisoners incorporated most of the General Assembly's views, ${ }^{20}$ the signatories specifically agreeing to elective repatriation. ${ }^{27}$ A Neutral Nation's Repatriation Commission was established to process all prisoner of war decisions on repatriation and to take custody of those not desiring to be returned. ${ }^{28}$ The agreement sought to maximize the discretion left to the individual captive through provisions that prevented repatriation from being the routine practice. According to its terms the right of repatriation had to be affirmatively asserted by the individual; it was not an automatic procedure which would be followed unless the prisoner objected. ${ }^{29}$ Those prisoners who did not affirmatively elect repatriation were released to civilian status after 120 days if the Commission did not determine that they actually preferred to be returned. ${ }^{30}$

The application of and declarations concerning the Convention by the global community during the Korean War thus reflected an acceptance of the concept that the prisoner of war had a right not to be forcibly repatriated. The communist nations originally did not concur in this interpretation of the Convention, but they eventually

25. The General Assembly ... 1. Affirms that the relcase and repatriation of prisoners of war shall be effected in accordance with the Geneva Convention Relative to the Treatment of Prisoners of War ... [,] the well-established principles and practice of international law and the relevant provisions of the draft armistice agrecment. 2. Affirms that force shall not be used against prisoners of war to prevent or effect their return to their homelands, and that they shall at all times be treated humanely in accordance with the specific provisions of the Geneva Convention and with the general spirit of the Convention.

G.A. Res. 610, 7 U.N. G.AOR Supp. 20, at 3, U.N. Doc. A/2361 (1952).

26. Text of Agreement on Prisoners of War (Korean War), 28 Dep't State Bull. 866 (1953) [hereinafter cited as Prisoner Agreement].

27. Id. sec. 1, para. 3, at 866 .

28. Id. sec. 1 , para. 1 , at 866 .

29. The agreement stipulated that "[w]ithin two months after the armistice agreement becomes effective, both sides shall . . . directly repatriate . . . all those prisoners of war in its custody who insist on repatriation to the side to which they belonged at the time of capture." Id. Preamble.

30. "The Neutral Nations Repatriation Commission shall declare the relief from the prisoner of war status to civilian status of any prisoners of war who have not exercised their right to be repatriated and for whom no other disposition has been agreed to by the political conference within 120 days . . . Id. sec. 4, para. 11, at 867 . 
accepted and acted in accordance with the principle in the Armistice Agreement of $1953 .^{31}$

\section{Changes in Circumstances}

Any covenant intended to apply to circumstances likely to change must be construed in a liberal manner ${ }^{32}$ and the Geneva Convention, as the International Red Cross commentary pointed out, was especially intended to be so interpreted..$^{33}$ Important changes have taken place since 1949 in the status of the individual in international affairs and international conflicts which provide part of the framework within which pertinent treaties should be interpreted.

The individual, from the time of the Geneva Convention, has benefited from what Professor Myres McDougal terms the growth in respect for human dignity in the international arena. ${ }^{34}$ The progress made in this direction is reflected in individual rights granted by treaties such as the Geneva Convention and in an enhanced status for the individual under international law. One result of individuals' recently heightened mobility is a growing emphasis on political awareness and the right freely to choose political affiliations and allegiances.

The tendency to view modern wars as ideological rather than territorial, another changed circumstance in international affairs, is also a reflection of the growing possibility that the individual may side with a new political order. Such an approach to warfare emphasizes control over people and their attitudes; changes of political allegiances are at least as strongly stressed as the conquest of territory. This change in approach extends to the treatment of prisoners of war. Under traditional war practices, in terms of which the Geneva Convention was written, there were often extensive efforts to encourage desertion among the enemy's combatants but little effort to alter allegiances among prisoners of war. International prescriptions

31. The declared end of hostilities in Vietnam did not resurrect this controversy because the two sides chose not to make forced repatriation a serious isste. It is apparent, however, that at least South Vietnam informally acted in accord with this interpretation by releasing many prisoners before they were to be repatriated. North Vietnamese failure to assert serious objection to this practice suggests some degree of concurrence by that nation with such a practice.

32. See M. McDougal, H. Lassiveli, J. Miller, The Interrretation of Agremenenis AND World PUblic ORder 98-100 (1967); Yoo, supra note 13, at 171.

33. FIvE Lessons, supra note 17 , at 17 .

34. See McDougal, Perspectives for an International Law of Human Dignity, 1959 Proc. Am. Soc. INT'L L. 107, 114-15. Human dignity is a principle which demands protection for the individual, his freedom and right to justice, and requires policies which offer him a maximum of choice and mobility. Id. 
relating to such prisoners were "applied on the assumption that a given person [was] a prisoner who continue[d] to owe allegiance to the captee state."35 With the advent of wars which the competing governments viewed in ideological terms, however, that assumption was no longer valid. The indoctrination of prisoners of war by captor nations has become a common element of modern international conflicts; such a change must be taken into consideration in interpreting the Geneva Convention. To engage in a policy of encouraging prisoners of war to alter their allegiances and forswear their native states but to deny them a subsequent right to refuse repatriation would be in accordance neither with the general purpose of the Geneva Convention nor with the standards of equity which also play a role in the interpretation of treaties. ${ }^{36}$

\section{Expectations of the Parties}

The expectations of the signatories to the Geneva Convention as to its proper construction are largely the result of the factors mentioned above-history, subsequent conduct, and changed circumstances. It is therefore unnecessary to deal with expectations as such in further detail. It is sufficient to note that the United States, which signed the covenant in 1955, became a party to the agreement at a time when expectations concerning its interpretation were already founded upon the document's previous application: the Korean Armistice agreement that limited the forcible return of prisoners.

In addition, the global community, through the United Nations General Assembly, had acknowledged that international law norms would play a role in the application of the Convention. These norms, as discussed below, ${ }^{37}$ today include the principle that an individual who reasonably fears a threat to his life or liberty upon return to his native state as the result of his race, religion, nationality, or political opinion has a right to refuse forcible repatriation.

All of these factors-the history and general purpose of the Convention, subsequent conduct of the signatories, changes in circumstances, expectations of the parties, and development of pertinent international law norms-must be weighed together with the text of the Geneva Convention in order to arrive at the most acceptable

35. Wilhelm, Can the Slatus of Prisoners of War Be Altered?, REvue INTERnationat. DE La Crolx-Rouge, July-Sept. 1953, at 20, quoted in R. Hiscorani, Prisoners of Wak 211 n.68 (1963) [hereinafter cited as Hisconani].

36. See M. Hudson, International. Tribunals 103 (1944).

37. See pp. 369.77 infra. 


\section{interpretation. Like any other treaty the agreement did not specifi- cally detail its application to all fact situations; ${ }^{38}$ when it must be}

38. It has bcen argued by past proponents of a narrow construction of the Convention that the subject of forcible repatriation was specifically dealt with by the treaty negotiators. This theory contended that the omission of a right to refuse repatriation was intentional and meant to reflect the absence of such an option. See, e.g., Vyshinsky Speech, supra note 12, at 37. This view was founded on the fact that the International Committee of the Red Cross mentioned the subject in the preliminary documents which it submitted to the commission of government experts convened to prepare a draft convention. Prelimisary Documests, supra note 4 , note to art. 68 , part IV, at 178 n.4. Although the government experts took "due note" of the International Committee's observations concerning repatration of prisoners of war against their will, they did not incorporate such a provision in their draft. INTERNATIONAL COMMITEE OF THE RED Cross, SumMary Relort of THE WORK OF THE CoNference of GovernMent Experts for tHL Study of the Conventions for the Protection of War Victias 95 (1947). The reasons for this omission were later explained by the representative diplomats during the Diplomatic Conference in Geneva in 1949. The major concern of the representatives was that if such a right were specified, the captor state would be required to grant permanent asylum-a conflict, they felt, with traditional state options in this area and an invitation to massive immigration. See II-A Final RECORD OF THE Diplomitic Conference of Genevi 291; II-B id. at 312-14 (1950); Charmatz \& Wit, supra note 3, at 403; Hingorani, supra note 35, at 212; Yoo, supra note 13, at 174. Of particular significance to the proponents of a narrow interpretation was the rejection by a large majority of these diplomats of the Austrian amendment to Article 118, which would have read in part, "l'risoners of War, however, shall be entitled to apply for their transfer to any other country which is ready to accept them." II-1, FINAL RECord, supra at 324,462 . This amendment had been proposed to ensure that "the prisoners of war [would] have the option of not returning to their country if they so desire[d]." Id. at 462 n.42.

Such an attempt to explain the intent of the original negotiators fails to take account of the nature of ihese conference discussions and their limited applicability to an interpretation of the final convention.

The significance of the diplomats' rejection of the Austrian proposal is easily magnified beyond its proper scope. The rejection of a proposal by such a conference does not mean that its opposite can be assumed as the voting parties' official position on an issue. As the International Court of Justice has specifically ruled, "[T] he fact that a particular proposal is not adopted by an international organ does not necessarily carry with it the inference that a collective pronouncement is made in a sense op. posite to that proposed. There can be many reasons determining rejection or nonapproval." Namibia Case, supra note 15, at 36 . In fact, though the parties refused to incorporate the right of nonrepatriation in the Convention explicitly, the diplomats did agree that existing international practice was to be taken into consideration in all situations where the Convention was applicable. Yoo 175. It is exactly such existing in. ternational practice which now supports the right of a prisoner of war not to be forcibly repatriated. See pp. $369-73$ infra.

Moreover, a survey of the diplomats' discussions reveals that they were concerncd with the problem of asylum for prisoners who did not want to be repatriated. The doctrine of asylum, which entails allowing an alien to remain in one's territory, how. ever, is not relevant to the present discussion of United States responsibility. Enemy combatants captured by American forces are rarely kept in United States territory. This does not extinguish American obligations in dealing with such prisoners. St'c pp. $369-70$ infra. It is the control over the prisoners, not their presence in American territory, which is the basis of a claim on their part against the United States under the Geneva Convention. In addition, as was the case in Korea, the granting of a pris. oner's request for nonrefoulment does not necessarily involve allowing him to remain in the state in which he was held prisoner. The right of the individual is only against repatriation, not against being sent to any other state which will accept him and in which he would be treated justly. The development of international law has includcd, moreover, an abandonment by the nations of the absolute discretion to refuse requests for nonrefoulment. See pp. 369-71 infra; Weis, Territorial Asylum, 6 INDLiN J. INT'L L., No. 2, at 181-87 (1966).

Even had due regard for such prevailing international law not been expressed, it must be remembered that the intentions of the parties at the time of signing the con. 
applied to circumstances not detailed, this total approach to assessing the Convention is most important. The factors discussed previously strongly support the contention that an individual right was created by the Geneva Convention for a prisoner of war to refuse repatriation in order to prevent his own persecution. As a signatory to the Convention, the United States is obligated to respect this individual option; a prisoner of war has the right to demand such respect.

\section{The Refugee Convention}

After the Second World War, the global community developed a unified interest in the aid and protection of refugees, abandoning its previous reliance on bilateral treaties. ${ }^{39}$ One response to the dislocation caused by this war was the 1951 Convention Relating to the Status of Refugees, ${ }^{40}$ which outlined the standards of treatment for refugees and recognized certain rights for their protection. In 1967, a Protocol to the Convention ${ }^{41}$ was opened which expanded its application. $4:$ The United States, which had not been a party to the original agreement, signed the Protocol in 1968.43

The important provision of the Convention is contained in Article 33: "No Contracting State shall expel or return ('refouler') a refugee in any manner whatsoever to the frontiers of territories where his life or freedom shall be threatened on account of his race, religion, nationality, membership of a particular social group or political opinion." 44 Like the Geneva Convention, the Refugee Convention is not strictly territorial in approach; its application does

vention are not the only factors to be considered in interpreting the agreement. Other relevant considerations-the history and general purpose of the Convention, subsequent conduct of the signatories, changes in circumstances, and development of international law norms-support the individual right of the prisoner. See pp. 362-67 supra.

39. Fragomen, The Refugee: A Problem of Definition, 3 CASE W.J. INT'L L., No. 1 , at $45,47(1970)$.

40. Convention Relating to the Status of Refugees, done July 28, 1951, 189 U.N.T.S. 150 [hereinafter cited as Refugee Convention].

41. Protocol Relating to the Status of Refugees, done Jan. 31, 1967, [1968] 19 U.S.T. 6224, T.I.A.S. No. 6577.

42. The original Convention restricted its definition of refugees to those whose displacement was caused by events prior to January 1, 1951. Refugee Convention, supra note 40, ch. 1, art. 1, def. A (2), at 152. Partially for this reason the United States had refused to become a party. The Protocol was drafted as a cure for this defect by incorporating the original convention minus the deadline for displacing events and some previous geographic restrictions. l'rotocol, supra note 41 , art. I, at 6225. The Protocol became effective November 1, 1968, for the United States.

43. It is the Convention Protocol which is therefore relevant to the present discussion. Refugee Convention shall hereinafter refer to the covenant as amended by the 1967 Protocol.

44. Refugee Convention, supra note 40 , art. 33, para. 1, at 176. 
not depend on aliens being within American territory nor does it impose a duty on the United States to allow refugees to enter its frontiers for the purpose of asylum. Though the travaux preparatoires gave no conclusive answer as to whether Article 33 applied to refugees other than those in the territory of a signatory, ${ }^{45}$ the wording: of the prohibition on refoulment supports an interpretation that the covenant was to apply to any refugee within the control of a contracting party. ${ }^{46}$

The circumstances surrounding the drafting of the Convention suggest a humanitarian intent to protect a broad range of refugees. The Convention was written in a period when the vast displacement of populations, the temporary governing of defeated nations by the victorious, the growing communications among states, and the emergence of individual rights in the international arena gave rise to a concern for control over people rather than simply over territory. In light of this background and the goal of refugee relief, the Convention was surely not intended to limit the scope of a refugee's protection against forcible return to a country at whose hands he feared persecution to the fortuitous circumstance of his successful penetration of the territory of a Contracting State. ${ }^{47}$ It is rather the control a nation may have over a refugee which makes the Refugee Convention relevant to an action on its part which would forcibly return that person "in any manner whatsoever" to a state in which he would face persecution.

\section{A. The Relationship of the Refugee Convention to the Geneva Convention}

It should be noted that the Refugee Convention represents a development in international law which plays a role in the interpretation of the Geneva Convention. The interpretation of any convention requires an examination of the agreement in the context of the general principles of that area of international law of which it is

45. See Weis, Territorial Asylum, supra note 38 , at 183 .

46. Under the maxim of treaty interpretation that words should not be considered redundant, the restriction on the "[expulsion] or return [refoulment]" of a refugec suggests that the Article's protection extended beyond those who were in a position to be expelled from a party's territory. Supporting this conclusion is the equating of "refouler" with "return" in the English text rather than with "cxpel." Refouler can be translated in more than one way; it can mean to expel aliens, to refuse entry, to drive back, or to force back. In order to avoid what would be a second redundancy in the relevant sentence, it must be assumed refouler means something other than to cxpel. All the other possible definitions refer to actions taken against those not already within the territory of the acting state.

47. Weis, Territorial Asylum, supra note 38 , at $183-84$. 
part. The meanings of words and phrases are implicitly the result of changing legal concepts and are grounded in changing legal doctrines, a fact repeatedly recognized by the signatories to the Geneva Convention through diplomatic conferences, declarations, and General Assembly resolutions. ${ }^{48}$ The recognition in the Refugee Convention of the principle of nonrefoulment of individuals to territory where they are threatened with persecution must be taken into account with respect to any application of the Geneva Convention as well.

The Refugee Convention also reflected changed expectations among the signatories in their abandonment of the claim to absolute discretion over whether to grant an alien's request for nonrefoulment. The confusion of this concept with that of asylum had been the most common argument against finding that the individual prisoner under the Geneva Convention might claim a right of nonrepatriation due to legitimate fears. ${ }^{49}$

The demise of that argument permits an interpretation of the Geneva Convention consonant with its humanitarian purpose, the subsequent conduct and expectations of the parties, changed circumstances, and the requirements of current international law norms.

\section{B. The Refugee Convention as a Separate Basis for the Prisoner's Right}

Before a prisoner of war captured by American forces can invoke the protections of the Refugee Convention, he must successfully expatriate himself and thus achieve refugee status. It has been argued, in opposition to recognition of a right of expatriation, that the options available to a prisoner of war are limited by his continuing military obligation to his country ${ }^{50}$ and that whatever rights of expatriation an individual may possess during times of peace are attenuated during wartime. The prisoner's right of expatriation under the Refugee Convention, therefore, depends upon his rights first as a prisoner of war and then as an individual.

The school of thought which views the prisoner of war as a captive military representative of his government with no choice as to expatriation and hence repatriation has been rejected both in theory and practice. The premise was rejected on a theoretical basis by the United States and other United Nations Command countries during

48. See pp. 361-62 \& note 33 supra; Namibia Case, supra note 15, at 31-32.

49. See note 38 supra.

50. Vyshinsky Speech, supra note 12, at 88. 
the Korean War. Those countries instead stressed the theory that the release and repatriation of prisoners of war required by the Geneva Convention were two separate steps. ${ }^{51}$ If that is true the released prisoner is at one time in a position to expatriate himself free of the complexities of his prisoner status. There is nothing inherent in the military status of a person in itself to negate the international right of expatriation, especially when hostilities have ceased. More important, the practice of states toward prisoners of war they have held negates any premise on their part that such prisoners have no rights of expatriation. Captor states have commonly carried on programs to encourage prisoners to alienate themselves from their native countries, programs which implicitly presuppose recognition of a right of expatriation. ${ }^{52}$

Apart from the capacity a prisoner of war may have to disavow his native state, as an individual in the international arena, he also has analogous rights which have built upon and converged with American policy to create current American obligations. The United States has formally recognized the right of any person to expatriate himself since $1868 . .^{53}$ Furthermore, the United States is bound by its own law to recognize the right of a prisoner of war to expatriate himself. ${ }^{\tilde{4}}$ Nor is it an impediment that the prisoner would thereby lack affiliation with any state. Since the right of expatriation is an inherent one, it is not dependent upon naturalization in a new

\section{See pp. 362-63 supra.}

52. Hingoraivi, supra note 35, at 210. In Vietnam the South Vietnamese openly admitted indoctrinating prisoners of war, the Chieu Hoi amnesty program being the most benevolent and hence the most advertised means. For a description of this program sce Wosepkat, Repatriation and the Chieu Hoi Amnesty Approach in I'ietnam: Conscquence and Prospects, 5 INT'L LAWYER 637 (1971).

53. An act of that year provided:

Whereas the right of expatriation is a natural and inherent right of all people...

Be it enacted ... that any declaration, instruction, opinion, order or decision of

any officers of this government which denies, restricts, impairs or questions the

right of expatriation is hereby declared inconsistent with the fundamental prin. ciples of this government.

Act of July 27, 1968, ch. 249 , 15 Stat. 223 , see 8 U.S.C. $\$ \$ 1481(a)(6)$, (7) (1970); cf. Mackenzic v. Hare, 239 U.S. 299 (1915); Elk v. Wilkins, 112 U.S. 94 (1884).

54. At one time the United States denied the right of its own citizens to expatriate themselves when the nation was at war. An Act in Reference to the Expatriation of Citizens and their Protection Abroad, ch. 2534, $\$ 2$, 34 Stat. 1228 (1907). This qualification was repealed by the Nationality Act of 1940 , Act of Oct. 14, 1940, ch. 876, $\$ 504,54$ Stat. 1172 (1910) (repealed by Act of June 27, 1952, ch. 477, $\$ 403(2)(42)$, 66 ) Stat. 280), is omitted from the current statutes on expatriation (8 U.S.C. $\$ 1181$ (a) (1970), and is "not now included in the American understanding of the doctrine." Liddel, The United States Position in Regard to the "Right of Expatriation," 23 Temp. L.Q. $325,370(1950)$. The current statute specifically provides for expatriation during wartime for those remaining outside the country in order to evade or desert military servicc. 8 U.S.C. $\$ \S 1481(a)(8),(10), 1483(a)$ (1970). 
country; by its exercise, the individual can separate himself from his native country and become stateless. ${ }^{55}$

Beyond national law, however, the individual has the right under international law to expatriate himself. For over a hundred years the United States has viewed expatriation as an international right of all people which cannot be abridged by any acts of the American government. ${ }^{50}$ It has likewise declared that all states are bound by this right and has refused to recognize any contention that a native state can make the option conditional. ${ }^{57}$ The United States position has developed wide, though not total, acceptance among other countries. By 1870, the British government abandoned its common law rule that allegiance was nonrevokable and enough nations followed suit that in 1924 the International Law Association gave formal approval to the American position. ${ }^{58}$ Finally, the international community implicitly recognized the right of expatriation in the Universal Declaration of Human Rights of 1948, which included in Article 15 that "no one shall be ... denied the right to change his nationality." 59

The United States' adherence to the concept of an international right of expatriation is central to a repudiation of the theory that an individual's right in this regard may be attenuated during times of war. It is an established principle that international, not national, law determines the relationship of an individual to a state and any

55. See Liddel, supra note 54 , at 364 . There is nonetheless some confusion in the American case law with respect to whether naturalization in a new state is a prerequisite of renunciation of allegiance to one's native state. Compare Leong Kwai Yin v. United States, 31 F.2d 738, 740 (9th Cir. 1929), with Perkins v. EIg, 307 U.S. 325, 334 (1939). Government officials have recognized that naturalization in a new country is not a necessary precondition to expatriation. See Opinion of the Principal Executive Officers of the Executive Department and Other lapers Relating to Expatriation, Naturalization and Change of Allegiance, at 10 (1873), quoted in Liddel, supra note 54, at 357. Cf. the opinion of Attorney General Black in 1940 in which this theme was leiterated. 9 OP. ATT'Y GEN. 62 (1940). Thus, the individual's right to expatriate himself and the right of a state to decide whom to admit as immigrants and whom to naturalize are distinct matters. See Liddel $355,358,364$.

56. See p. 372 supra.

57. The American delegate to a Hague Conference on nationality, for example, opposed an article which sought to deny renunciation of nationality until an expatriation permit was granted by the native state on the grounds that it implied "an admission that it is a reasonable and proper thing for a state to require its express permission before one of its nationals can change his nationality . . " Flournoy, Nationality Contention, Protocols and Recommendations Adopted iy ihe First Conference on the Codification of International Law, 24 AM. J. INT'L L. 467, 473 (1930).

58. See Harvard Rescarch in International Law, Draft Convention on the Law of Nationality (Comment on Article 13), 23 AM. J. INT'L L. 45, 47 (1929 Supp.).

59. Universal Declaration of Human Rights, art. 15, G.A. Res. 217A, 3 U.N. GAOR Supp. 535, 538, U.N. Doc. A/777 (1948). If the Declaration has assumed significance as customary international law, the right of expatriation is thereby a binding norm. See pp. 379.80 infra. 
national rules on expatriation must give way if there is a conflict.0" Whatever laws a nation may have in regard to the expatriation of its nationals, those individuals have independent status and rights in the international arena to abandon their prior allegiances and obligations. Such a disparity between rights on national and international levels is not uncommon. When the native state has control over its own national, it may decide to enforce its own domestic laws; but when an individual is beyond the control of his native state, as in the case of a prisoner of war, other nations are obligated to respect his international rights. Since the principle of an absolute international right of expatriation is recognized by the United States and most other nations, the right cannot be attenuated during time of war by a particular domestic law. Through the exercise of this right, a prisoner of war, like any other alien outside his country, may sever the ties to his native state.

While the right of a prisoner of war to expatriate himself is thus clear, it is still necessary to establish that the expatriate prisoner of war is protected by the Refugee Convention. If the prisoner exercised his right of expatriation in order to avoid repatriation for fear of persecution, he has brought himself within the second definition of "refugee," as used in the Convention, which reads:

any person who ... [,] owing to well-founded fear of being persecuted for reasons of race, religion, nationality, membership of a particular social group or political opinion, is outside the country of his nationality and is unable, or, owing to such fear, is unwilling to avail himself of the protection of that country .... ${ }^{01}$

This definition is based, of course, upon such vague concepts as a "well-grounded fear" and "persecution." Fear being a personal emotion, "the circumstances and background of the person, his psychological attitude and sensitivity toward his environment play a role as well as the objective facts . ..."02 In order to give some substance to the definition, however, the United Nations Ad Hoc Committee on Statelessness and Related Problems explained that "well-founded fear" meant that "a person [had] either actually been a victim of persecution or [could] show good reason why he fears

60. See Schwarzkopf v. Uhl, 137 F.2d 898 (2d Cir. 1943); Nottebohm Case, [1955] I.C.J. 4; Flegenheimer Case (United States v. Italy), 5 Decisions Italian-United States Conciliation Commission Case No. 20, Dec. No. 182 (1959).

61. Refugee Convention, supra note 40 , ch. 1 , art. $1, \$ \mathrm{~A}(2)$, at 152 .

62. Weis, The Concept of the Refugee in International Law, 87 Journal DE DroIr INTERNATIONAL 928, 970 (1960) [hereinafter cited as Weis, The Concept of the Refugee]. 
persecution."03 This definition, in turn, hinges upon what may be considered persecution. According to Article 33 of the Refugee Convention, the contracting parties are forbidden to send a refugee to a territory where his life or liberty would be threatened on account of the reasons outlined in the Convention; this would appear to be one instance of persecution as used in the Convention's definition of refugee. Other grievances, such as disregard for human dignity ${ }^{\text {c.t }}$ or deprivation of economic opportunities, ${ }^{65}$ might also constitute valid claims of persecution.

Recent declarations with respect to communist refugees have given a broad meaning to the definition of possible persecution and have recognized subjectively reasonable fears. On November 23, 1970, a Lithuanian seaman jumped from a Russian ship onto an American Coast Guard cutter and refused to be repatriated for fear that his life or freedom would be put in danger. When the United States forcibly returned him, the United Nations High Commissioner for Refugees, under his general competence to oversee the protection of all international refugees, made it known that he considered such an action a violation of the Refugee Convention. ${ }^{66}$ When a Yugoslavian seaman sought to prevent his forced return to Yugoslav authorities, based upon his demand for protection from persecution under the Immigration and Naturalization Act, the Ninth Circuit held that the standard for determining the likelihood of persecution was not whether the alien could obtain some employment in his home state; rather the inquiry must be whether he might suffer economically for his political opinions. ${ }^{67}$ Whether a prisoner of war who refused repatriation would be a refugee as defined by the Refugee Convention is thus a question of fact, as any determination under the

63. Report of the Ad Hoc Committec on Statelessness and Related Problems, U.N. Doc. E/1618, at $39(1950)$. The substitution of a standard of a "good reason to fear" for a "well-founded fear" does not resolve the definitional question. The terminology of the Convention makes an objective enquiry difficult, for it outlines no standards as to what may cause a justifiable fear, nor does it address itself to the issue of a captor state encouraging such fear. Nonetheless, the Convention must be applied to factual situations and the most logical solution appears to be that nations should respect a plausible basis for fearing persecution as measured by the reasonable man standard central to the law of torts.

64. Weis, The Concept of the Refugee, supra note 62 , at 970 .

65. The Immigration and Naturalization Act authorizes the Attorney General to withhold the deportation of an alien to any country where he would be subject to persecution because of race, religion, or political opinion. 8 U.S.C. $\$ 1253(\mathrm{~h})(1970)$. The federal courts have interpreted this statute to include a wide range of conduct constituting persecution, including incarceration, corporal punishment, and the deprivation of economic opportunitics. Fragomen, supra note 39 , at 54 n.34.

66. N.Y. Times, Dec. 1,1970 , at 11 , col. I.

67. Kovac v. Immigration \& Naturalization Service, 407 F.2d 102 (9th Cir. 1969). But see Cheng Kai Fu v. Immigration \& Naturalization Service, 386 F.2d 750 (2d Cir. 1967). 
Convention is. If his fear of persecution is well founded, he would be covered by its protections.

It may be noted that the Convention's definition of refugee differs somewhat from the more common usage of the word in that it draws no distinction between an individual who originally left his country as part of its armed forces and one who fled as a result of immediate possible danger. The Convention is applicable to any person who is "outside the country of his nationality"; he need not have left originally for any specific motive but only must be outside the country and unwilling to return because of reasons within the scope of the Convention. ${ }^{68}$ The actions of the individual while outside his native state may themselves give rise to the well-founded fear of persecution that entitles him to be considered a refugee, ${ }^{69}$ as may be the case with a prisoner of war who openly disavows his country. No viable distinction can be drawn which would separate such prisoners from other refugees protected by the Convention. ${ }^{70}$

Once the prisoner of war who has reason to fear persecution in his home country is recognized as a refugee under the Refugee Convention, the protection he seeks against repatriation must also be granted. By demonstrating that he has reasonable cause to fear for his life or freedom on account of his race, religion, nationality, membership of a particular social group, or political opinion, he establishes a private right against the United States, as party to the Convention, to refuse repatriation under Article 33. While that Article is phrased in terms of prohibitions against the actions of contracting

68. See Weis, The Concept of the Refugee, supra note 62, at 972.

69. See Fragomen, supra note 39 , at 55 .

70. See Charmatz \& Wit, supra note 3 , at 408 . Such reasoning has been reflected in the practice of the Soviet Union, which, while rejecting the right of any citizen to nonrepatriation, has never separated prisoners of war from the general category of Soviet citizens, refugees, and displaced persons. See Ginsburgs, The Soviet Union and the Problem of Refugees and Displaced Persons, 1917-1956, 51 AM. J. INT'L L. 325, 359 (1957). Section $F$ of Article 1 of the Refugee Convention does exclude those who there is reason to believe are guilty of war crimes, crimes against humanity or peace, or acts contrary to the purposes of the United Nations. Admittedly, those guilty of war crimes may not be entitled to the total protection of the Refugee Convention, just as they do not receive full benefits from the Gencva Convention; but such persons are only a small percentage of prisoners of war. As to crimes against peace and hu. manity, the position of the American government is that these charges are not usually applicable to general combatants but apply instead to national leaders who plan and initiate wars. AMERICAN ENTERpRISE INSTITUTE, ThE Prisoner OF WAR Problem 19. Analysis No. 26 (1970) [hereinafter cited as AEI]. The standard of exclusion for acts contrary to the purposes of the United Nations is very obscure and ap. parently has never been applied. It was interpreted by many of the delegates to the diplomatic conference to apply only to those who collaborated with enemies of the United Nations during the Second World War. Weis, The Concept of the Refuget, supra note 62 , at 986 . In regard to any of these exceptions, it must be remembered that the Convention should be interpreted in compliance with its general purpose of extending protection to the vast majority of the world's refugees. 
states, its benefits inure to the individual and can theoretically be invoked by him through Article 16;11 a personal international right can thus be asserted.

\section{Customary International Law}

International rights and obligations often develop through less formal, specific channels than the modality of interstate agreements which characterizes conventional international law. In fact, these agreements often reflect what has already become binding through the evolution of customary law standards. Customary law is formed by the continuous, uniform conduct of nations in a way that creates expectations that such conduct will continue in the future and is required by international law. ${ }^{72}$

By their actions, declarations, and policies, the governing elites of nation states create expectations that such particular conduct is obligatory; the expectations created substitute for a formal written agreement officially binding all nations which become parties. An examination of governments' past actions, agreements, and statements reveals the prevalent expectation of two evolved norms which have ripened into felt international obligations of the United States: (1) An individual may possess personal rights against a state under international law; (2) There should be no forced return of aliens to states in which they would be persecuted for their beliefs, race, or status. These two norms, in combination, constitute the prisoner of war's right of nonrepatriation.

\section{A. Personal Rights Under International Law}

Traditionally, only nation states were considered subjects of international law and hence able to possess international rights. The trend away from this view began, to a significant degree, immediately after World War II-most notably with the Charter of the United Nations. ${ }^{73}$ The Charter was followed in 1948 by the Universal Dec-

71. "A refugee shall have free access to the courts of law ... of all contracting States." Refugee Convention, supra note 40 , art. 16.

72. See The Lotus Case, [1927] P.C.I.J., Ser. A, No. 9, at 18.

73. Tucker, Has the Individual Become the Subject of International Law?, $34 \mathrm{U}$. CrN. L. Rev. 341, 357 (1965). In the Preamble to the Charter, the "peoples of the United Nations ... [reaffirmed their] faith in fundamental human rights, in the dignity and worth of the human person, in the equal rights of men and women . . . " Article One asserts as a purpose of the United Nations the development of respect for "the principle of equal rights and self-determination of peoples" and for "human rights and fundamental frecdom." U.N. CharTer ch. 1, art. 1, paras. 2, 3. 
laration of Human Rights, ${ }^{74}$ which was intended to be a clear recognition that the individual possessed certain universal rights, recognized in the international arena, which derived independently of the laws of his native state. It was significant in this respect that the provisions of the Declaration were not phrased as limitations on state action but as specific, positive, personal rights.

The principle of private international rights has since been recognized on numerous occasions by the global community. The United Nations has produced a number of conventions which recognize the individual as a possessor of international rights: among others, the Refugee Convention, the International Covenant on Civil and Political Rights, ${ }^{75}$ the International Covenant on Economic, Social and Cultural Rights, ${ }^{76}$ and those on statelessness, ${ }^{77}$ slavery, ${ }^{78}$ and forced labor. ${ }^{79}$ In addition, a number of United Nations declarations, including the Declaration on Territorial Asylum, ${ }^{30}$ the Declaration of the Rights of the Child, ${ }^{81}$ the Declaration on the Granting of Independence to Colonial Countries and Peoples, ${ }^{82}$ and the Declaration on the Elimination of All Forms of Racial Discrimination, ${ }^{83}$ acknowledge the individual as a subject of international law. As a result of this flow of agreements and statements, the principle that the individual holds personal rights in the international arena has developed into a customary norm. ${ }^{84}$

\section{B. The Right Against Forcible Return to Territories of Likely Persecution}

One of the customary norms an individual, as a subject of international law, has a right to rely upon is the expectation against forced repatriation where the alien has a valid fear of persecution in his home country. Resolutions subscribed to by the global community,

74. See note 59 supra.

75. G.A. Res. 2200, 21 U.N. GAOR Supp. 16, at 52, U.N. Doc. A/6316 (1966).

76. Id. at 49.

77. Convention Relating to the Status of Stateless Persons, done September 28, 1954, 360 U.N.T.S. 117.

78. Supplementary Convention on the Abolition of Slavery, the Slave Trade, and Institutions and Practices Similar to Slavery, done September 7, 1956, 266 U.N.T.S. 3.

79. Convention Concerning the Abolition of Forced Labour, adopted June 25, 1957, 320 U.N.T.S. 291; see Svarlien, International Law and the Individual, 4 J. PUB. L. 138 (1955).

80. G.A. Res. 2312, 22 U.N. GAOR Supp. 16, at 81, U.N. Doc. A/6716 (1967).

81. G.A. Res. 1386, 14 U.N. GAOR Supp. 16, at 19, U.N. Doc. A/4354 (1959).

82. G.A. Res. 1514, 15 U.N. GAOR Supp. 16, at 66, U.N. Dac. A/4684 (1960).

83. G.A. Res. 1904, 18 U.N. G.AOR Supp. 15, at 35, U.N. Doc. A/5515 (1963).

84. See P. Jessui, A Modern LAw of Nations 15-17 (1968); Tucker, supra note 73, at 366 . 
such as those passed in the General Assembly of the United Nations, have played a significant role in the evolution of this principle. ${ }^{85}$ Resolution 610 (VII), which gave rise to the expectation against forced repatriation in the context of the Korean Armistice agreement on the exchange of prisoners, has been discussed above. ${ }^{80}$ Of greater importance has been the Universal Declaration of Human Rights, ${ }^{87}$ which serves as the foundation for the entire range of international protection for the individual. While the Declaration does not deal expressly with forced repatriation, the totality of its articles reflects a standard of protection from the persecution that such a forced return would entail. ${ }^{88}$ If a prisoner of war or any individual could claim that, upon his forced repatriation, such rights would be denied him by his native state due to his beliefs, race, or status, he would be asserting a threatened breach of the Declaration's stipulation that "[e]veryone is entitled to all the rights and freedoms set forth in this Declaration, without distinction of any kind, such as . . . religion, political or other opinion, national or social origin . . . ."so Moreover, the repatriating state, by forcing the alien to return home in the face of such probable results, would be violating its obligation "by progressive measures, national and international, to secure [the] universal and effective recognition and observance" of these rights. ${ }^{\text {o }}$

Originally, the Declaration was seen simply as a statement of principles approved by the global community as a common standard of achievement; 01 but "[i]n the years since 1948 [it] has acquired a pur-

85. While resolutions and declarations are not binding in the same sense that treaties are, they can accelerate the growth of a customary norm. By declaring that a certain principle is binding, a resolution avoids the necessity of continuous state practice to show uniform approval and a belief on the part of states that they must act according to that principle: "[T] ogether with prior and subsequent conforming conduct, the resolution 'creates' a customary law by fulfilling the precondition of recognition," Bleicher, The Legal Significance of Re-Citation of General Assembly Resolutions, 63 AM. J. INT'L L. 445, 450 (1969). See also A Memorandum of the Office of Legal Affairs to the Committee on Human Rights, U.N. Doc. E/CN. 4/ L. 610 (1962). Cf. O. AsamosH, The Legal Sicnificance of the Declarations of the General Assembly of the United Nations 47.63 (1966); E. SChwelb, HuMAN Rights and the InTERnational ComMUNITY 70 (1964) [hereinafter cited as SchwelB]; Cheng, United Nations Resolutions on Outer Space: "Instant" International Customary Law?, 5 INDIAN J. INT'L L. 23, 36-46 (1965).

86. See p. 366 supra.

87. See note 59 supra.

88. The Declaration states that everyone has a right to "life, liberty and the security of person" (Article 3), "to freedom of thought, conscience and religion" (Article 18), to "freedom of opinion and expression" (Article 19), and "to leave any country" (Article 13); moreover "[n]o one shall be held in slavery or servitude" (Article 4) and "[n]o one shall be subjected to . . cruel, inhuman or degrading treatment or punishment" (Article 5).

89. Id. Article 2, $\$ 1$.

90. Id. Preamble.

91. Aries, International Human Rights and Their Implementation, 19 GEO. WASH. L. REv. 579, 593 (1951). 
pose different from the one which was contemplated and willed by many of the governments that brought it into being .... . It was the international community ... that used the Declaration ... [and] through unplanned, haphazard action ... invested [it] with an increased . . . authority and practical importance." 92 The Declaration has been incorporated into numerous conventions, declarations, and even some state constitutions as a universal standard. ${ }^{93}$ As a result of this constant and widespread recognition, the Declaration has assumed the nature of customary international law, ${ }^{04}$ a development proclaimed by the Montreal Assembly of Human Rights in 1968.15 The implicit right to refuse repatriation to territories of probable persecution has therefore likewise become an established norm.

Conventions, too, play a role in the formation of customary law, not because they codify a principle which might not otherwise be binding but because they help to create expectations of state action. These expectations are in turn the basis of customary standards which are obligatory on all nations, not just those party to the convention. The Refugee Convention fulfilled this function in regard to repatriation of aliens facing persecution, a result recognized by the later Conference on Stateless Persons. ${ }^{96}$

As discussed above the Geneva Convention and its application had

92. ScHwels, supra note 85 , at 37 .

93. By 1967, for instance, the Declaration had been incorporated in 75 United Nations resolutions. Bleicher, supra note 85 , at 444 . In two cases the General Assembly gave the Declaration equal standing with the Charter and resolved unanimously that both were binding provisions of international law. The 1960 Declaration on Colonialism, supra note 82 , stated that "all states shall observe faithfully and strictly the provisions of the Charter of the United Nations, the Universal Declaration of Human Rights and the present convention." The 1963 Declaration on the Elimination of Racial Discrimination, supra note 82 , included a similar provision. The Declaration on Colonialism is of spccial significance because it included an elaborate enforcement mechanism which demonstrates that it was more than a statement of principle. 'The 1962 vote reaffirming the Declaration on Colonialism amounted therefore to an agreement by the global community to be bound by its provisions, including compliance with the Universal Declaration. Sec $\Lambda$. Robertson, Human Rights IN THE WORLD 28 (1972); SchwelB, supra note 85, at 68-70; Waldock, Human Rights in Contemporary International Law and the Significance of the European Convention, INr's \& Comp. L.Q. Supp. No. 11, at 1, 13, 14 (1965). For the rule that states abstaining in a vote on a resolution declaring customary law are considered bound by the resulting resolution, see Bleicher, supra note 85, at 451 .

The acceptance of the Declaration as a definition of the term "human rights" as used in the Charter, cf. Bleicher 462, has also supported its binding character since the Charter has been ruled to be an obligatory international document on those nations that signed it. Namibia Case, supra note 15 , at 715 .

94. See A. RoBertson, supra note 93, at 28; Waldock, supra note 93, at 14; cf. Bleicher 458-65.

95. The Assembly formally acknowledged that "the Universal Declaration of Human Rights ... has over the years become a part of customary international law." U.N. Doc. A/Conf. 32/28, at 2, quoted in A. Robertson, supra note 93, at 28 n.14.

96. A conference resolution stated "that Article 33 of the Convention Relating to the Status of Refugees of 1951 is an expression of [a] generally accepted principle...." Conference on Stateless Persons, U.N. Doc. E/Conf. $17 / 5$, at 5 (1954). 
a central role in the initial development of the concept that a person might have a right, under certain circumstances, to refuse to be returned to his native state. The controversy concerning the Convention's application gave rise during the Korean War negotiations to official statements by members of the international community which created expectations of state conduct. Forced repatriation was declared repugnant not only to the humanitarian purpose of the Convention $^{97}$ but also to the ideals of justice and liberty ${ }^{98}$ and to the totality of values of the free world. ${ }^{99}$ The United States even went so far as to declare it illegal. ${ }^{100}$

Finally, state domestic law and practice have created expectation ${ }^{\circ}$ of limitations on forcible repatriation. In some nations there has developed a concurrent acceptance of the right of an alien to territorial asylum. In Germany, for example, persons who are refugees as defined in the Refugee Convention are granted asylum under national law. ${ }^{101}$ While the United States, in common with other nations, has not incorporated a right of asylum into national law, it has recognized its responsibility to aliens threatened with persecution in the Immigration and Naturalization Act. ${ }^{102}$ Whether required by national law or not, moreover, almost all nations have consistently granted at least temporary asylum to aliens fleeing political persecution. ${ }^{103}$ So consistent has this state policy been, in fact, that nonrepatriation of aliens threatened with persecution has become a binding customary international norm. ${ }^{104}$

The development of customary international law thus reveals recognition by the global community of the principle against repatriation of aliens to territories in which they face persecution. This norm does not rest in its application upon the status of the alien. It is irrelevant in this context whether the protection is considered a pro-

97. See note 20 supra.

98. Yoo, supra note 13 , at 171 .

99. Speech by British Foreign Secretary Anthony Eden, in Charmatz \& Wit, supra note 3, at 392 .

100. In a speech before the Political and Security Committee of the United Nations in 1952, Secretary of State Dean Acheson said, "So far as I know, there has been no member of the United Nations outside the Communist group that has ever suggested that it was right, proper, legal or necessary to return [Korean] prisoners by force. ... [I] $\mathrm{t}$ would be highly immoral and illegal to force these prisoners to return . . . ." D. Acheson, supra note 1 , at 30 .

101. Asylum Ordinance of January 6, 1953, [1953] BGBI I 3.

102. 8 U.S.C. \$ $1253(\mathrm{~h})(1970)$.

103. Krenz, The Refugee as a Subject of International Law, 15 INT'L \& Comp. L.Q. $90,108(1967)$.

104. See id. at 104 for the view that uniform practice by states constitutes another source of international law principles as recognized by Article 38 of the Statute of the International Court of Justice-"the general principle of law recognized by civilized nations." 
hibition against state action or a direct right of the individual. It can only be claimed by the individual prisoner himself, once he has rejected his native state, which would normally represent his claims in the international arena. The ability of the prisoner of war to make such claims directly has been recognized by the concurrent customary norm that the individual may possess rights apart from those of any particular state. ${ }^{105}$

\section{Conclusion}

Since World War II most nations which have been parties to armed conflicts have respected the requests of prisoners of war not to be repatriated at the end of hostilities. Nevertheless, the prisoner of war remains in a precarious position with respect to forced repatriation as long as doctrine recognizes in the captor state discretion over the matter, for his fate may thus be determined by political necessities. For this reason the United States should recognize a personal right in prisoners of war captured by it to refuse repatriation to territory where they would face persecution.

It is important, moreover, that the United States take the formal

105. There are two further concepts of international law closely related to the principle of nonrepatriation which should at least be noted. The first is the ideal of human dignity, discussed at p. 366 supra. If this ideal, which has become a norm of the international community, prohibits forced repatriation of an alien, such action would deprive him of fundamental rights.

Secondly, the right of a threatened prisoner of war to refuse repatriation draws substance from the role of equity in settling issues of international law. The applicability of equity to international controversies is recognized in Article 38, paragraph 2, of the Statute of the International Court of Justice, and "a decision-maker is thus not confined in determination of lawfulness, to explicit agreements or inferences from prior customary behavior, but may draw creatively upon a great variety of principles, precedents, analogies and considerations of fairness." H. Steiner \& D. Vacts, Transnational. Legal Problems 207 n.36 (1968). As Professor Myres MICDougal has pointed out, “[F]or all types of controversies, the one test that decision-makers have in fact invoked and applied is that simple and ubiquitous, but indispensable, standard of what, considering all relevant policies and variables in context, is reasonable . . ." McDougal, Editorial Comment: The Hydrogen Bomb Tests and the International Law of the Sea, 49 AM. J. INT'L L. 356,359 (1955).

In the context of the present discussion, the principle of equity would dictate against repatriating prisoners of war who have deserted during imprisonment. Captor states commonly pursue an active program of encouraging desertion among prisoners of war, the most current example of which is the Chieu Hoi program in Vietnam and its Communist counterpart. See p. 367 supra. To surrender such a prisoner, who is either a political refugee or a deserter who has renounced his allegiance on express or implied promises of protection, would be both a breach of good faith on the part of the captor state and a violation of the international principles of equity. See Hingorani, supra note 35, at 213; Schapiro, Repatriation of Deserters, 29 BRIT. Y.B. INT'L L. 311,323 (1952). 
step of declaring its recognition of that right. Such declaration at this time would serve multiple purposes. First, since it could be rendered during a period of relative peace for American military forces, discussion of the principle would not be impeded by the political ramifications of a war in which the United States was capturing and losing prisoners of war. In this freer atmosphere, a declaration would be instrumental in furthering the global community's recognition of the right and would undoubtedly lead to a dialogue which would further clarify the details of its application. Second, in the event that the United States became involved in later war, this prior declaration of a prisoner's right would facilitate its exercise. Many prisoners with valid justification to refuse repatriation might be hesitant to assert their claims unless they were certain of success, especially since the means of enforcement are limited ${ }^{\mathbf{1 0 6}}$ and a denial of the request would almost certainly mean punishment in their home country. Finally, the declaration would clarify the protection which the American government expected its military authorities (and those of any nations to which it transferred prisoners) to accord prisoners of war they captured, thus promoting the practical realization of the right's observance. Regardless of what American authorities might do behind the scenes in fulfilling the nation's responsibility in this respect, the absence of a clear recognition and declaration of the right of nonrepatriation by the American government would confuse its position on the subject and undoubtedly af-

106. As compared to domestic law, there are obvious difficulties in regard to the enforcement of international rights. This is especially true when rights are those of an individual instead of a state. With the exception of the European human rights court, individuals usually have no standing before one of the important mediums of cnforcement-international tribunals. This does not mean their rights do not exist, but it does mean that for some violations of an individual right there may be no direct personal remedy. See Tucker, supra note 73 , at 344 .

The difficulties of enforcement of private rights seem even more incongruous with respect to a right which can be personally invoked by an individual, such as the prisoner of war. The distinction which should be kept in mind is between the right to invoke an international claim and the effective power to enforce it.

The picture is certainly not totally bleak. In all probability, the United States would abide by its obligations to respect his right in order to continue its efforts to live up to its international obligations and to prevent adverse public opinion and criticism domestically and internationally.

It might be added that the United States need create no burden for itself by respecting the prisoner's claim. In situations such as Vietnam, the nation in which the captive was held is willing to allow him to remain in its territory and eventually become a citizen. Even were this not so, the United States would be under no obligation to grant the prisoners asylum in American territory. The United Nations Office of the High Commissioner for Refugees was created to handle displaced persons such as these and to facilitate their transfer to other nations. See Statute of the Office of the United Nations High Commissioner for Refugees, G.A. Res. 428, 5 U.N. GAOR Supp. 2, U.N. Doc. A/I750, 1751 (1950). 
fect the likelihood that the right would be both demanded and respected.

The ambiguities which may attend the application ${ }^{107}$ of this doctrine make it even more important that the United States understand its responsibilities before it is again involved in a military action in which prisoners of war are captured, so that it can take the necessary steps from the outset to ensure that the right of nonrepatriation is supported.

107. United States participation in the Vietnam War raised practical questions involved in application of the right of nonrepatriation of prisoners captured in a guerrilla conflict. An immediate issue is the transfer of prisoners captured by American forces to the client state's control. It appears likely that the prisoners may assert personal rights against the United States, including nonrepatriation, under such circumstances. 